\title{
Import diversification along the growth path
}

\author{
Esteban Jaimovich* \\ Collegio Carlo Alberto, Via Real Collegio 30, Turin (10024), Italy
}

\section{A R T I C L E I N F O}

\section{Article history:}

Received 16 February 2012

Received in revised form

11 May 2012

Accepted 30 May 2012

Available online 8 June 2012

\section{JEL classification:}

F10

F14

Keywords:

Bilateral trade

Import diversification

Product variety

\begin{abstract}
A B S T R A C T
We provide evidence showing that the degree of diversification of import sources of finely disaggregated commodities rises monotonically along the growth path. This result is robust to different measures of import diversification and the inclusion of a large set of additional control variables. In addition, we show the process of rising import diversification takes place as countries gradually increase their spending shares in imports originating from relatively distant exporters.
\end{abstract}

(c) 2012 Elsevier B.V. All rights reserved.

\section{Introduction}

The recent literature on bilateral trade flows has established a peculiar empirical regularity: countries tend to purchase their imports from relatively few available sources. ${ }^{1}$ As a striking example, Haveman and Hummels (2004) find that, when defining commodities by the 4-digit Standard International Trade Classification (SITC) categorisation, $58 \%$ of importers buy their imported commodities from less than $10 \%$ of the available exporters. In other words, bilateral trade flows data is plagued with zeros.

The number of zeros, although ubiquitous and large in relative terms, has not remained constant across time. Broda and Weinstein (2006) and Sauré (forthcoming) found that the 'zeros' in the bilateral trade data display a downwards trend over time-the former article looks only at US data while the latter looks at cross-country data. Such an increase in the number of trading partners has been deemed a side-effect of the secular rise in per capita incomes in the world. The argument is the following: as real incomes grow, consumers' love-of-variety rises. Wealthier individuals then widen the set of varieties they consume, which in turn leads to an expansion of the sources/exporters from where they purchase their goods.

\footnotetext{
I would like to thank Ainhoa Aparicio-Fenoll, Alina Sandor and an anonymous referee for useful comments.

* Tel.: +39011 6705055; fax: +390116705082.

E-mail address: esteban.jaimovich@carloalberto.org.

1 E.g., Haveman and Hummels (2004), Besedeš and Prusa (2006), Broda and Weinstein (2006), Helpman et al. (2008), Baldwin and Harrigan (2011) and Chen (2012).
}

These stylised facts concerning the 'zeros' in the bilateral trade data are certainly interesting in their own right. However, they fall short of giving a thorough characterisation of the degree of diversification of imports, and how import diversification varies with the level of income of the importer. In particular, the discreetness implied by treating trade links as a binary variable (that is, either we observe 'positive trade' or 'zero trade') disregards large amounts of useful information contained in the data.

In this paper, we contribute to the above-mentioned literature by studying the evolution of import diversification along the growth path. We use two different measures of import diversification at the product level: (i) the Gini coefficient for value of imports by source; (ii) the (normalised) Herfindahl index for import shares by source. Both measures of diversification, which are described in further detail in the next section, make use of all the available information in terms of total value of imports by source. ${ }^{2}$

In terms of results, Section 3 shows that import diversification increases monotonically along the growth path. This results remains robust to the inclusion of a large set of additional controls, such as product, importer, product-importer, and time dummies. In addition, in Section 4, we provide some suggestive evidence concerning the geographical pattern of import diversification: the data suggests that imports diversification takes place as countries

\footnotetext{
2 Imbs and Wacziarg (2003) have previously used the Gini coefficient and the Herfindahl index to measure the degree of concentration of labour and value added across different sectors in the economy. In this paper, we apply a similar methodology, but we use it to measure the degree of diversification of imports of finely disaggregated goods in terms of country of origin of those imports.
} 
shift part of their (import) spending shares from nearby exporters to more distant ones.

An important question that naturally arises is why we should actually care about the degree of diversification of import sources within product categories. There are two main reasons why diversification by source country might encompass important economic consequences on productive efficiency and welfare. First, products from different countries within the same category may well differ in some of their characteristics. As a result, if varieties supplied by different exporters are not perfect substitutes, either in the case they refer to intermediates to be combined in the production final goods (as in Ethier (1979), Kasaharaa and Rodrigue (2008), and Halpern et al. (2011)) or in the case they refer to final consumption goods (as in Armington (1969), Hallak (2006), and Ardelean and Lugovskyy (2010)), a larger set of import sources will raise welfare. Second, as already noted by Caselli et al. (2011), in the presence of country-specific shocks, an expanding set of import sources entails also an important insurance component. Essentially, a larger set of trading partners allows better diversification of country-level shocks that may affect a specific exporter, since importers may then mitigate those shocks by shifting part of their spending to other country-suppliers.

\section{Data and measures of import diversification}

Our main data source is Feenstra et al. (2005). This dataset compiles bilateral trade data by commodities for the years 1962-2000. Traded commodities are organised according to the 4-digit SITC (revision 2). In total, there are 1004 different commodities in the SITC-4 classification. We use the data on value of imports of each SITC- 4 commodity (by country of origin of the commodity) to compute two different measures of import diversification by commodity-importer-year: the Gini coefficient for inequality of sources of imports, and the normalised Herfindahl index for concentration of import shares.

To compute the Gini coefficients, we first order, from smallest to largest, the total value of imports of each commodity by export source, considering all active exporters of the commodity in a given year. Notice this includes the cases when purchases by an importer from an exporter in a given year are actually equal to zero. Next, after ordering the value of imports by source, we apply the following formula:

$$
\operatorname{GINI}_{i, m, t}=2 \frac{\sum_{x=1}^{N_{i, t}} x V_{m, i, t, x}}{N_{i, t} \sum_{x=1}^{N_{i, t}} V_{m, i, t, x}}-\frac{1+N_{i, t}}{N_{i, t}} .
$$

$\mathrm{GINI}_{i, m, t}$ yields the value of the Gini coefficient of imports of commodity $i$, by importer $m$, in year $t . V_{m, i, t, x}$ denotes the value of imports of product $i$, by importer $m$, in year $t$, originating from exporter $x$-each exporter $x$ has been numerically ordered within the sum in (1) according to their value of exports of $i$ to $m$ in $t$, from smallest to highest, including those who exported zero. $N_{i, t}$ is the total number of active exporters of $i$ in $t$ : an active exporter of $i$ in $t$ is a country that has exported a strictly positive amount of good $i$ at least to one importer in year $t$.

The value of the normalised Herfindahl index of import shares of commodity $i$, by importer $m$, in year $t$, is computed as follows ${ }^{3}$ :

\footnotetext{
3 We have also run all the regression displayed in Section 3 for the case of the (standard) Herfindahl index: $\sum_{x=1}^{N_{i, t}}\left(V_{m, i, t, x} / \sum_{x=1}^{N_{i, t}} V_{m, i, t, x}\right)^{2}$. The regression results using the Herfindahl (which are available from the author upon request) are very similar to those using (2)
}

$H E R F_{i, m, t}=\frac{\sum_{x=1}^{N_{i, t}}\left(\frac{V_{m, i, t, x}}{\sum_{i, t} V_{m, i, t, x}}\right)^{2}-N_{i, t}^{-1}}{1-N_{i, t}^{-1}}$.

Lower values of either $G I N I_{i, m, t}$ or $H E R F_{i, m, t}$ indicate a more diversified provision of good $i$ in period $t$ in terms of sources, given the total number of active exporters of $i$ in $t\left(N_{i, t}\right)$.

The rest of the data we use include: income per capita (in PPP) and population taken from Heston et al. (2011), and the distance (in kilometers) between exporter and importer obtained from Mayer and Zignago (2006).

Table 1 reports some summary statistics for the income per capita, Gini, normalised Herfindahl and number of active exporters $\left(N_{i, t}\right)$. In the dataset there are 5940 observations with a Gini coefficient equal to 0 . These extreme observations essentially correspond to the cases in which $N_{i, t}$ equals 1 (i.e., there exists only one active exporter of good $i$ in $t) .{ }^{4}$ In these peculiar cases the normalised Herfindahl index is not well-defined (so, we lose these observations in the regressions involving $\left.H E R F_{i, m, t}\right)$. We should stress that our regressions in Section 3 will control for the number of active exporters by including one dummy variable for each of the possible values taken by $N_{i, t}{ }^{5}$ As a final remark, it might look striking the fact that the Gini coefficients lie so overly concentrated near unity. This is the consequence of the relatively large presence of zero trade between active exporters and importers in the dataset.

\section{Import diversification and growth}

This section reports our main empirical results. Tables $2 \mathrm{~A}$ and 2B present a series of regressions with $\mathrm{GINI}_{i, m, t}$ and $H E R F_{i, m, t}$ acting as dependent variable, respectively. Except for column (4), all regressions contain the logarithm of income per capita as the independent variable of main interest; in column (4) we use instead the level of income per capita. In all regressions we add the level of population as independent variable, in case the overall size of the economy may somehow influence the extent of diversification of imports (for example, due to the presence of sunk costs in the creation of trade links). In addition, we always include time dummies; these would control for any possible common trends in import diversification (for example, owing to time trends in transport costs), or the common effect of some major global shock impacting the intensity of trade (for example, an oil shock).

In column (1) of Table $2 \mathrm{~A}$, we regress the Gini coefficient on the aforementioned variables, including also product and importer dummies. The former would take care of the facts that different commodities are generally offered by different sets of exporters. ${ }^{6}$ The latter would control for time-invariant importer characteristics, such as area, climate diversity, being landlocked or an island, etc.. The regression shows that the log income per capita correlates negatively with the value of the Gini coefficients. This result suggests that, as economies become richer, they tend to purchase their imports of finely disaggregated products from a more diversified set of exporters of those products.

\footnotetext{
4 More precisely, there are 5936 observations (representing $0.24 \%$ of all observations) in which $N_{i, t}=1$; the other four cases in which $\operatorname{GINI}_{i, m, t}=0$ correspond to observations with $N_{i, t}=2$.

5 An alternative to this, though more demanding in terms of total number of regressors, would be to include time-product dummies.

6 In particular, the product dummies would control for the bias that may be generated if richer countries tend to allocate a larger share of their spending on goods offered in general by a larger set of exporters, for which there is thus greater scope for diversification of export sources.
} 
Table 1

Summary statistics.

\begin{tabular}{lcllll}
\hline & Mean & Median & St. dev. & Min & Max \\
\hline GDP pc (in 1000 PPP US dollars) & 7.57 & 3.76 & 9.00 & 0.118 & 74.3 \\
Gini & 0.953 & 0.966 & 0.059 & 0 & 0.993 \\
Normalised Herfindahl & 0.547 & 0.488 & 0.309 & 0 & 1 \\
Number of active exporters $\left(N_{i, t}\right)$ & 54.94 & 54 & 29.9 & 1 & 160 \\
\hline
\end{tabular}

Number of observations: Gini 2,468,374; normalised Herfindahl 2,462,438.

In column (2) we introduce a dummy variable for each of the possible values taken by $N_{i, t}$ in the dataset. We do so in case the (time-invariant) product dummies alone turn out to be not enough to fully control for the possible bias generated by the presence of a heterogeneous set of exporters across products and time (this may actually occur if there is substantial variation of the value of $N_{i, t}$, within products, across time). As we can observe, the results in column (2) are essentially identical to those in column (1), although the $R$ squared does rise substantially.

The regression in column (3) includes a full set of importerproduct dummies. Importer-product dummies are able to control for some additional features not taken care of by (1) or (2), such as the relative distances of a specific importer from the main export sources of a specific product, or the level of self-sufficiency of the country in a specific product. Although slightly smaller (in absolute value) than in columns (1) and (2), our main correlation of interest remains negative and highly significant. As a robustness check, column (4) reports the results of the same regression, but using the level of income per head instead of its logarithm-the negative and significant correlation remains in place.

As additional robustness check, in columns (5) and (6) we split the sample and run two separate regressions with the same set of independent variables used in (3). In the former we use only the observations for which $N_{i, t}<56$, while in the latter we include only those for which $N_{i, t}>56$. That is, we take the sub-samples in which the number of active exporters is below and above the sample median, respectively. The rationale for this is that our correlation of interest may vary significantly at different levels of $N_{i, t}$, since the scope for increasing the level import diversification in a given product will be somehow conditioned by $N_{i, t}$. The results in (5) and (6) yield two main insights. First, in both sub-samples the log of income per head and the Gini are negatively correlated. Second, although the partial correlation coefficient in (6) is slightly larger than in (5), their difference is statistically not significant.

All the previous regressions are conducted under the assumption that the correlation between import diversification and income per head remains the same at all levels of per capita income. However, one may worry about the validity of this assumption. In particular, one may want to rule out the possibility of a nonmonotonic relationship between the two variables. In columns (7)-(10) we proceed to approach this issue. In order to do so, we split the dataset into four sub-samples determined by the income per capita quantiles, and run separate regressions for each of the quantiles. The correlation of interest is negative across the board. We do, however, find an interesting pattern concerning the estimates: the association between the log of income per head and import diversification becomes steeper as economies get richer; in other words, the process of import diversification speeds up along the growth path.

Finally, Table $2 \mathrm{~B}$ reports the results obtained when using the normalised Herfindahl as the dependent variable in the regressions. As we can observe, all the main results remain essentially intact under this alternative measure of import diversification. ${ }^{7}$

\footnotetext{
7 The only qualitative difference appears in the quantile regressions-columns (7)-(10). When diversification is measured using the normalised Herfindahl index, the speed of diversification seems to slightly slow down along the growth path (although the differences in the point estimates are far from being significant).
}

\section{Diversification and distant markets}

Section 3 remains silent as to whether there is some general pattern regarding how the diversity of import sources by commodity rises along the growth path. In this section we present some results suggesting that import diversification goes hand in hand with a rise in import shares originating from relatively distant markets. In a sense, such a relationship between diversification and distance sounds theoretically intuitive: it suggests that loveof-variety leads individuals to expand the set of varieties they consume by gradually adding commodities originating from less accessible markets.

We compute the average distance of imports of commodity $i$ $\left(\right.$ AvgDist $\left.t_{i, m, t}\right)$ by averaging the bilateral distance between exporter $x$ and importer $m\left(\right.$ Dist $\left._{m, x}\right)$, where the variable Dist $_{m, x}$ is weighted by the share of imports of $i$ originating from $x$. Namely,

AvgDist $_{i, m, t}=\sum_{x=1}^{N_{i, t}}\left(\operatorname{Dist}_{m, x} \times \frac{V_{m, i, t, x}}{\sum_{x=1}^{N_{i, t}} V_{m, i, t, x}}\right)$.

In Table 3 we conduct a series of regressions with AvgDist $t_{i, m, t}$ acting as dependent variable. All regressions include year dummies, importer-product fixed effects, a set of dummies for each of the possible values taken by $N_{i, t}$ in the dataset, and the importer's population.

The regressions in columns (1) and (2) contain only one additional regressor each: in the former this is the logarithm of income per head, while in the latter the Gini coefficient. The regression in (1) yields a positive coefficient for the income variable, although the level of significance does not reach $10 \%$. On the other side, the regression in (2) produces a positive coefficient on the Gini, and is highly significant.

Next, in column (3), we run a regression including simultaneously the log income per head and Gini. Interestingly, the Gini keeps its point estimate and level of significance essentially intact. By contrast, the coefficient associated to income per head falls quite drastically, and as a result it turns highly non-significant. From columns (4) and (5) we may observe that the same qualitative results also arise when using the normalised Herfindahl to measure import diversification (moreover, the drop in the point estimate of the coefficient associated to log income per capita is quantitatively more pronounced when adding $H E R F_{i, m, t}$ to regression (1) than when adding IINI $_{i, m, t}$ to it).

Taken all together, the regressions in Table 3 point towards a particular geographical pattern of diversification of import sources. The rise in import diversification seems to take place as more distant exporters increase their market shares along the importer's growth path. In addition, the regressions appear to rule out the presence of a strong "direct" income effect, whereby a rise in income per head allows the substitution of nearby exporters with more distant ones. Instead, it seems to be the case that higher income per capita leads to a rise in the average distance of import sources through its (positive) effect on import diversification. This result is consistent with the idea that loveof-variety leads individuals to expand the set of varieties they consume by gradually adding commodities originating from less accessible markets. 
Table 2A

Dependent variable: Gini coefficient by good and importer (multiplied by 100 ).

\begin{tabular}{|c|c|c|c|c|c|c|c|c|c|c|}
\hline & \multicolumn{4}{|l|}{ Full sample } & \multirow{2}{*}{$\begin{array}{l}N_{i, t}<56 \\
(5)\end{array}$} & \multirow{2}{*}{$\begin{array}{l}N_{i, t}>56 \\
(6)\end{array}$} & \multicolumn{4}{|c|}{ Income per capita split by quantiles } \\
\hline & $(1)$ & $(2)$ & (3) & (4) & & & $\begin{array}{l}\text { Q1- }(<1.18) \\
(7)\end{array}$ & $\begin{array}{l}\text { Q2-(1.18; 3.76) } \\
(8)\end{array}$ & $\begin{array}{l}\text { Q3-(3.76; 10.17) } \\
\text { (9) }\end{array}$ & $\begin{array}{l}\text { Q4- }(>10.17) \\
(10)\end{array}$ \\
\hline \multirow{2}{*}{$\begin{array}{l}\text { Log income per } \\
\text { capita }\end{array}$} & -1.430 & -1.454 & -1.304 & & -1.251 & -1.363 & -0.716 & -0.912 & -1.054 & -1.622 \\
\hline & $(0.126)^{* * *}$ & $(0.130)^{* * *}$ & $(0.137)^{* * *}$ & & $(0.177)^{* * *}$ & $(0.126)^{* * *}$ & $(0.104)^{* * *}$ & $(0.187)^{* * *}$ & $(0.378)^{* * *}$ & $(0.481)^{* * *}$ \\
\hline Population & $\begin{array}{l}-0.053 \\
(0.011)^{* * *}\end{array}$ & $\begin{array}{l}-0.056 \\
(0.011)^{* * * *}\end{array}$ & $\begin{array}{l}-0.053 \\
(0.008)^{* * *}\end{array}$ & $\begin{array}{l}-0.091 \\
(0.009)^{* * * *}\end{array}$ & $\begin{array}{l}-0.056 \\
(0.007)^{* * * *}\end{array}$ & $\begin{array}{l}-0.050 \\
(0.012)^{* * *}\end{array}$ & $\begin{array}{l}-0.013 \\
(0.006)^{* * *}\end{array}$ & $\begin{array}{l}-0.109 \\
(0.032)^{* * * *}\end{array}$ & $\begin{array}{l}-0.270 \\
(0.109)^{* *}\end{array}$ & $\begin{array}{c}-0.040 \\
(0.064)\end{array}$ \\
\hline Income per capita & & & & $\begin{array}{l}-0.100 \\
(0.017)^{* * * *}\end{array}$ & & & & & & \\
\hline Year dummies & YES & YES & YES & YES & YES & YES & YES & YES & YES & YES \\
\hline Product dummies & YES & YES & - & - & - & - & - & - & - & - \\
\hline Importer dummies & YES & YES & - & - & - & - & - & - & - & - \\
\hline $\begin{array}{l}\text { Importer-product } \\
\text { dum. }\end{array}$ & - & - & YES & YES & YES & YES & YES & YES & YES & YES \\
\hline Dummies for $N_{i, t}$ & NO & YES & YES & YES & YES & YES & YES & YES & YES & YES \\
\hline Observations & $2,334,149$ & $2,334,149$ & $2,334,149$ & $2,334,149$ & 816,834 & $1,517,315$ & 419,801 & 536,073 & 638,534 & 739,785 \\
\hline$R$ squared & 0.36 & 0.85 & 0.92 & 0.91 & 0.95 & 0.77 & 0.95 & 0.94 & 0.95 & 0.85 \\
\hline
\end{tabular}

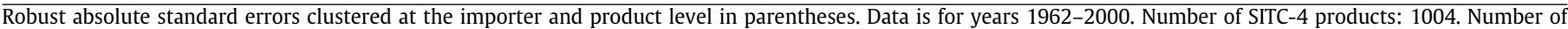
importers: 160. Income per capita is measured in thousands of 2005 US dollars (PPP adjusted). Population is measured in 10 million people.

* Significant at $10 \%$.

*** Significant at $5 \%$.

Significant at $1 \%$

Table 2B

Dependent variable: normalised Herfindahl index by good and importer (multiplied by 100).

\begin{tabular}{|c|c|c|c|c|c|c|c|c|c|c|}
\hline & \multicolumn{4}{|l|}{ Full sample } & \multirow{2}{*}{$\begin{array}{l}N_{i, t}<56 \\
(5)\end{array}$} & \multirow{2}{*}{$\begin{array}{l}N_{i, t}>56 \\
(6)\end{array}$} & \multicolumn{4}{|c|}{ Income per capita split by quantiles } \\
\hline & (1) & $(2)$ & (3) & (4) & & & $\begin{array}{l}\text { Q1-(<1.18) } \\
(7)\end{array}$ & $\begin{array}{l}\text { Q2-(1.18; 3.76) } \\
(8)\end{array}$ & $\begin{array}{l}\text { Q3-(3.76; 10.17) } \\
(9)\end{array}$ & $\begin{array}{l}\text { Q4- }(>10.17) \\
(10)\end{array}$ \\
\hline \multirow{2}{*}{$\begin{array}{l}\text { Log income per } \\
\text { capita }\end{array}$} & -13.478 & -13.767 & -13.300 & & -12.24 & -13.98 & -12.829 & -12.240 & -12.416 & -10.429 \\
\hline & $(1.33)^{* * *}$ & $(1.32)^{* * * *}$ & $(1.45)^{* * * *}$ & & $(1.59)^{* * *}$ & $(1.45)^{* * *}$ & $(1.85)^{* * * *}$ & $(2.51)^{* * * *}$ & $(3.71)^{* * * *}$ & $(3.78)^{* * * *}$ \\
\hline Population & $\begin{array}{l}-0.504 \\
\quad(0.091)^{* * * *}\end{array}$ & $\begin{array}{l}-0.502 \\
\quad(0.089)^{* * * *}\end{array}$ & $\begin{array}{l}-0.499 \\
\quad(0.091)^{* * * *}\end{array}$ & $\begin{array}{l}-0.836 \\
\quad(0.171)^{* * *}\end{array}$ & $\begin{array}{l}-0.485 \\
\quad(0.091)^{* * * *}\end{array}$ & $\begin{array}{l}-0.471 \\
\quad(0.101)^{* * * *}\end{array}$ & $\begin{array}{l}-0.170 \\
(0.102)^{*}\end{array}$ & $\begin{array}{c}-0.298 \\
(0.288)\end{array}$ & $\begin{array}{l}-2.245 \\
(0.966)^{* *}\end{array}$ & $\begin{array}{c}-0.862 \\
(0.580)\end{array}$ \\
\hline Income per capita & & & & $\begin{array}{l}-0.687 \\
(0.135)^{* * * *}\end{array}$ & & & & & & \\
\hline Year dummies & YES & YES & YES & YES & YES & YES & YES & YES & YES & YES \\
\hline Product dummies & YES & YES & - & - & - & - & - & - & - & - \\
\hline Importer dummies & YES & YES & - & - & - & - & - & - & - & - \\
\hline $\begin{array}{l}\text { Importer-product } \\
\text { dum. }\end{array}$ & - & - & YES & YES & YES & YES & YES & YES & YES & YES \\
\hline Dummies for $N_{i, t}$ & NO & YES & YES & YES & YES & YES & YES & YES & YES & YES \\
\hline Observations & $2,328,503$ & $2,328,503$ & $2,328,503$ & $2,328,503$ & 811,188 & $1,517,315$ & 418,854 & 534,732 & 635,960 & 738,963 \\
\hline$R$ squared & 0.41 & 0.43 & 0.63 & 0.63 & 0.66 & 0.64 & 0.53 & 0.60 & 0.62 & 0.70 \\
\hline
\end{tabular}

Robust absolute standard errors clustered at the importer and product level in parentheses.

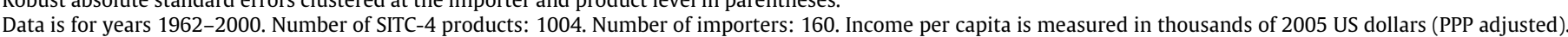
Population is measured in 10 million people.

" Significant at $10 \%$.

** Significant at $5 \%$.

**** Significant at $1 \%$.

Table 3

Dependent variable: average distance of imports (weighted average).

\begin{tabular}{|c|c|c|c|c|c|}
\hline & $(1)$ & $(2)$ & (3) & $(4)$ & (5) \\
\hline Log income per capita & $\begin{array}{l}199.4 \\
(140.7)\end{array}$ & & $\begin{array}{l}135.2 \\
(139.5)\end{array}$ & & $\begin{array}{l}110.3 \\
(136.1)\end{array}$ \\
\hline Gini $\times 100$ & & $\begin{array}{l}-47.4 \\
\quad(12.47)^{* * * *}\end{array}$ & $\begin{array}{l}-49.2 \\
\quad(12.53)^{* * *}\end{array}$ & & \\
\hline Normalised Herfindahl $\times 100$ & & & & $\begin{array}{l}-6.54 \\
\quad(1.13)^{* * * *}\end{array}$ & $\begin{array}{l}-6.66 \\
(1.14)^{* * *}\end{array}$ \\
\hline Population (in $10,000,000$ ) & $\begin{array}{l}-27.7 \\
\quad(5.87)^{* * *}\end{array}$ & $\begin{array}{l}-27.7 \\
(5.54)^{* * * *}\end{array}$ & $\begin{array}{l}-30.4 \\
(5.79)^{* * *}\end{array}$ & $\begin{array}{l}-28.5 \\
\quad(5.35)^{* * *}\end{array}$ & $\begin{array}{l}-30.6 \\
(5.72)^{* * *}\end{array}$ \\
\hline Year dummies & YES & YES & YES & YES & YES \\
\hline Importer-product dummies & YES & YES & YES & YES & YES \\
\hline Dummies for $N_{i, t}$ & YES & YES & YES & YES & YES \\
\hline Observations & $2,334,119$ & $2,468,282$ & $2,334,149$ & $2,462,346$ & $2,328,503$ \\
\hline$R$ squared & 0.71 & 0.71 & 0.71 & 0.71 & 0.72 \\
\hline
\end{tabular}

Robust standard errors clustered at the importer and product level in parentheses. Number of products: 1004 . Number of importers: 160. Data is for years 1962-2000. The dependent variable is constructed using distances from exporter and importer obtained from Mayer and Zignago (2006) weighted by the import share originating from each of the exporters.

* Significant at $10 \%$.

** Significant at $5 \%$.

Significant at $1 \%$. 


\section{Concluding discussion: theoretical mechanisms}

The main aim of the paper is descriptive: to show a robust positive correlation between the degree of import diversification by source and the importer's income per head. It is however interesting to conclude by connecting the previous correlation to some theoretical mechanisms recently studied by the trade literature. There exist two main explanations for the positive correlation between import diversification by source and income per capita: non-homothetic preferences and fixed costs involved in setting up trade links.

Concerning non-homothetic preferences, there may be different channels that lead to an expansion of the set import sources of consumed goods over the growth path. The simplest possibility is that individuals display love-of-variety that rises with the level of aggregate consumption. Alternatively, Sauré (forthcoming) shows that, even when love-of-variety remains constant, the presence of 'iceberg' trade costs which differ by sources may make consumers behave as if they actually had non-homothetic preferences, by expanding the variety of imported goods when their income rises. ${ }^{8}$ Another possible explanation is that non-homothetic preferences are the result of willingness to pay for quality that rises with income. Based on this argument, Jaimovich and Merella (2011) show that, in the presence of trade costs only high-quality varieties get traded, and thus consumers with rising incomes increase their imports as a side-effect of consumption quality upgrading. In addition, the mechanisms proposed by Saure (forthcoming) and by Jaimovich and Merella (2011), seem both to also fit well with the evidence in Table 3, by implying that import diversification goes hand-in-hand with higher import penetration from less accessible suppliers.

The second possible explanation is fixed trade costs, as they will mean that international trade becomes profitable only for sufficiently large import markets. Such a mechanism is quantitatively investigated by Tarasov (2012) within a general equilibrium model featuring identical consumers with homothetic love-of-variety preferences. Similar results would arise as well in a model where local firms import different varieties of intermediate inputs to be combined in a CES production function, as proposed by Halpern et al. (2011). Nevertheless, these two alternative models differ in an important dimension regarding causality direction: in the former, income growth leads to a larger set of imported varieties; in the latter, it is also the case that an expansion in the variety of intermediates entails a productivity effect, hence it feeds back on income growth.
An interesting extension to the current paper would be to investigate whether the correlations presented here are mainly the result of demand side (i.e., nonhomotheticities) or supply side (i.e., fixed trade costs) factors. This could require the structural estimation of a general equilibrium trade model, from where we may next back out fundamental parameters related to preferences and cost functions. We leave this open to future research.

\section{References}

Ardelean, A., Lugovskyy, V., 2010. Domestic productivity and variety gains from trade. Journal of International Economics 80, 280-291.

Armington, P.S., 1969. A theory of demand for products distinguished by place of production. International Monetary Fund Staff Papers 16, 159-178.

Baldwin, R., Harrigan, J., 2011. Zeros, quality and space: trade theory and trade evidence. American Economic Journal: Microeconomics 3, 60-88.

Besedeš, T., Prusa, T., 2006. Ins, outs, and the duration of trade. Canadian Journal of Economics 39, 266-295.

Broda, C., Weinstein, D., 2006. Globalization and the gains from variety. Quarterly Journal of Economics 121, 541-585.

Caselli, F., Koren, M., Lisiky, M., Tenreyro, S., 2011. Diversification Through Trade. LSE.

Chen, Wei-Chih, 2012. Innovation and duration of exports. Economics Letters 115, 305-308.

Ethier, W., 1979. Internationally decreasing costs and world trade. Journal of International Economics 9, 1-24.

Feenstra, R., Lipsey, R., Deng, H., Ma, A., Mo, H., 2005. World trade flows: 1962-2000, NBER Working Paper No. W11040.

Hallak, J.C., 2006. Product quality and the direction of trade. Journal of International Economics 68, 238-265.

Halpern, L., Koren, M., Szeidl, A., 2011. Imported Inputs and Productivity. CEU.

Haveman, J., Hummels, D., 2004. Alternative hypotheses and the volume of trade: the gravity equation and the extent of specialization. Canadian Journal of Economics 37, 199-218.

Helpman, E., Melitz, M., Rubinstein, Y., 2008. Estimating trade flows: trading partners and trading volumes. Quarterly Journal of Economics 123, 441-487.

Heston, A., Summers, R., Aten, B., 2011. Penn World Table Version 7.0. In: Center for International Comparisons of Production, Income and Prices, University of Pennsylvania.

Imbs, J., Wacziarg, R., 2003. Stages of diversification. American Economic Review 93, 63-86.

Jaimovich, E., Merella, V., 2011. Love for quality, comparative advantage, and trade. In: Carlo Alberto Notebooks \#216. Collegio Carlo Alberto.

Kasaharaa, H., Rodrigue, J., 2008. Does the use of imported intermediates increase productivity? plant-level evidence. Journal of Development Economics 87, $106-118$.

Mayer, T., Zignago, S., 2006. GeoDist: the CEPII's distances and geographical database, MPRA Paper 31243.

Sauré, P., 2011. Bounded love of variety and patterns of trade, Open Economies Review (forthcoming).

Simonovska, I., 2010. Income differences and prices of tradables, NBER WP 16233.

Tarasov, A., 2012. Per capita income, market access costs, and trade volumes. Journal of International Economics 86, 284-294.

\footnotetext{
8 A key assumption in Sauré (forthcoming) concerning preferences is that, although marginal utility is decreasing, it is bounded away from zero. As a result, a consumer (who is not sufficiently rich) may choose to leave some (of the more expensive) imported varieties unconsumed. See also Simonovska (2010) for a model based on a similar key assumption.
} 